\title{
Research on Current Status of LBS Industry Development in Beijing
}

\author{
Qiong $\mathrm{Wu}^{1, \mathrm{a}^{*}}$, Nanxin $\mathrm{Li}^{2, \mathrm{~b}}$, Ru $\mathrm{Liu}^{3, \mathrm{c}}$ \\ ${ }^{1,2,3}$ Science Popularization Research Dept.
}

\author{
Beijing Institute of Science and Technology Information Beijing, China \\ a E-mail: wwqqppdd@163.com, ${ }^{\mathrm{b}}$ E-mail:33570506@qq.com, ${ }^{\mathrm{c}}$ E-mail:rudyliu1983@hotmail.com
}

Keywords: Beijing; Local-based service (LBS) industry; current status

\begin{abstract}
The current status, development course, policy environment and business patterns of LBS industry are summarized and analyzed in the present essay. Some current questions are pointed out and several important suggestions are made for promoting the development of LBS industry.
\end{abstract}

\section{Current Status of LBS industry development in Beijing}

As the basic, strategic information resources for a country, geographic information is the backbone for the national economy and information technology construction. Beijing, as the cultural and political center of the whole country, gained its great advantages in every segment of geographic information industry, especially getting fast development in the top hi-tech aspect of the industry chain. Beijing Municipal Government and National Administration of Surveying, Mapping and Geoinformation of China (NASG) had co-built National Geographic Information Technology Industry Park and Unistrong satellite navigation Industrial Park, which take the full advantages of Beijing as the capital of China to speed up the development of geographic information industry. Meanwhile, National Geographic Information Technology Industry Park and Unistrong satellite navigation Industrial Park will offer great support for further propelling the adjustment of industrial structure and speeding up the change of its development mode in Beijing.

\subsection{Development course of LBS industry development in Beijing}

On Nov. 11, 2010, Beijing Municipal People’s Government and NASG signed a framework agreement of the strategic cooperation on building National Geographic Information Technology Industry Park, which was launched formally on March, 2011 in Shunyi District, Beijing. In June 2012, National Geographic Information Technology Industry Park was officially recognized as Beijing national geoinformation new high-tech industrial base by Ministry of Science and Technology of the People's Republic of China. The Industry Park covers about $666667 \mathrm{~m}^{2}(1000 \mathrm{Mu})$ area, with a total investment of 15 billion. On Dec. 20, 2012, with the great opening of National Geographic Information Technology Industry Park, it remarked the first state-level geographic information technology industry had been officially put into use. More than 100 domestic and international corporations relevant with geographic information were introduced after the completion of the Industry Park. A state-level new high-tech industry park with an annual output nearly 100 billion and the employees more than 60 thousand was formed, which has become a core and demonstrative base of geographic information industry in China[1].

On the list of first 25 corporations entering the Industry Park, several are from Beijing including NavIfor Co., Ltd., AutoNavi Software Co. Ltd., Lingtu Software Technology Co. Ltd. and so on. In 2012, the number of enterprises and institutions entered the Industry Park was over 50, which included 5 scientific research institutes, 26 new high-tech enterprises, 6 listed companies, 3 scientific R\&D institutions above the provincial or ministerial levels, more than 10 intermediaries, 2 engineering centers above the provincial or ministerial levels, 3 Beijing enterprise technology centers and 5 key labs[2]. 


\subsection{Policy environment of LBS industry development in Beijing}

Standing Committee Member of CPC, Beijing Municipal Committee discussed and passed the "Science and Technology Beijing" Action Plan (2009-2012) in 2009. In the Action Plan, it points out that "we should promote the development of electronic information industry, greatly develop internet value added service, information service, mobile-phone value added service and digital TV mass media value added service etc. " In the "Twelfth Five Year” Beijing Development and Construction Plan on Science and Technology released by Beijing Municipal Government in 2011, information technology, modern transport technology, and earth observation and navigation location service technology are regarded as the important bases of forefront technology and the development of new industry. Meanwhile, the massive spatial data processing, intelligent traffic technology, transportation system information and other key technologies are considered as main breakthrough technologies for Beijing. The remote sensing and geographic information system, navigation \& positioning technology are listed as important technology system needed to be established. Beijing Municipal Government released Beijing Implementation Guideline on Accelerating the Cultivation and Development of Strategic New Industry on July 21, 2011, in which it points out "to support the development of BeiDou Navigation Satellite System". All of these policies must be the significant motivation to promote the great-leap-forward development of Chinese location service industry for a long time in the future. Beijing Municipal Commission of Economy and Information Technology together with the relevant departments, scientific research institutes and key enterprises launched the editing work for "BeiDou Navigation and location service industry development implementation”. A number of BeiDou application and industrial development key demonstrative projects are planned and selected to build a projects reserve pool based on a deep investigation and the through experts arguments. On this basis, Beijing City to Promote BeiDou Navigation and Location Service Industry Development Implementation (2012-2015) was formed. During the five years, various policies have become the important motivation for promoting the great-leap-forward development of Beijing location information service industry, and they will be work for a long time in the future.

At the same time, Beijing LBS industry has closely connected with the development of many technologies. The R\&D of some state-level important and special projects like the high-resolution earth observation system, BeiDou Navigation Satellite System, and new generation broadband wireless mobile communication technology are directly correlated with LBS industry. Moreover, the current major work moved forward in Beijing including Triple-play and Smart Beijing is closely connected with the development of LBS industry. For instance, the four tasks in Smart Beijing Action Plan- "precise management of urban population" "traffic intelligent management service" "intelligent monitoring of resources and ecological environment" and "intelligent control of city safety"-are all correlated with LBS technology. And the speeding up of Triple-play is bound to bring about more derived application products on mobile internet market. These products and their application must be beneficial for LBS industry.

\subsection{Business patterns of LBS industry development in Beijing}

The customers of LBS can be divided into government \& enterprise users and public users. Different user groups have different application requirements. The application requirements of government \& enterprise users are position monitoring and scheduling the vehicles, people, and goods, etc. This kind of users includes logistics enterprises, taxi companies, passenger transport companies, emergency vehicles, and shipping enterprises and so on[3]. 
Table 1 LBS main product features for government \& enterprise users

\begin{tabular}{|c|c|}
\hline Functions & Descriptions \\
\hline Goods management and searching & $\begin{array}{l}\text { RFID \& positioning equipment seamless } \\
\text { connection } \\
\text { Searching for vehicles, pallets, manifests, and } \\
\text { car distribution lists and so on }\end{array}$ \\
\hline Logistics statistics analysis & $\begin{array}{c}\text { Cargo information statistics } \\
\text { Travel route statistics } \\
\text { Operation statistics } \\
\text { Driver's performance appraisal statistics }\end{array}$ \\
\hline Logistic Scheduling & $\begin{array}{c}\text { Real-time positioning } \\
\text { Vehicle tracing } \\
\text { Prescription route and alarming with line cross } \\
\text { Vehicle scheduling } \\
\text { Service and rescue, regional early warning } \\
\text { Investigation and evidence collection, scheduling } \\
\text { and distribution }\end{array}$ \\
\hline System management & $\begin{array}{l}\text { User management, positioning equipment } \\
\text { Vehicle management, driver management }\end{array}$ \\
\hline
\end{tabular}

Public users mainly require the service of personal positioning and navigation, surrounding information searching, the third part positioning, dating software application, commercial advertisements and e-business and so on.

Table 2 LBS main product features for public users

\begin{tabular}{c|c}
\hline Functions & Descriptions \\
\hline Personal positioning and navigation & $\begin{array}{c}\text { Personal geographic positioning, route navigation } \\
\text { Driving geographic positioning and navigation }\end{array}$ \\
\hline The third part positioning & $\begin{array}{c}\text { Mobile map searching } \\
\text { Surrounding information searching (hotel, service } \\
\text { station, shop etc) }\end{array}$ \\
Dating software application & Family tracking and positioning \\
\hline Commercial advertisements & $\begin{array}{c}\text { Good friends searching and positioning } \\
\text { Virtual community combined location service } \\
\text { Games based on location }\end{array}$ \\
\hline & $\begin{array}{c}\text { Customer ads service } \\
\text { Food and beverage booking, discount service }\end{array}$ \\
\hline
\end{tabular}

\section{Current questions}

\subsection{Lacking of industrial plan and policy guidance}

As the industrial service mode of LBS run for a short time in Beijing, the government haven't a unified industrial development plan and matched macro-control policies, which lead to an unmatched situation among the industrial service providers, navigation electronic map producers and the consumers. The lack of a strong running mechanism brings about a relative retarded situation on information service industrial development in Beijing[4].

\subsection{Various levels of mapping data resources}

There is not a standard on collecting and organizing the geographic information resources. The content of information is shortage. At present, the mapping data cannot meet users' needs, because of 
series problems like low precision of mapping data products, different levels on geographic information content, non-real time information updating, slow inquire speed and so on. All of these problems lead to a low identification of spatial information. Data collection is lack of the support of unified technical standard. The mode of data collection is confusion chaos. The software platforms are incompatible with building redundant projects[5].

\subsection{Lacking innovation on commercial modes}

The current main application modes of LBS industry include user sign-in, shared position, getting the winner badge, electronic coupons, and comment on shops, location navigation, searching and inquiring. Searching and inquiring means user can gain practical information by inquiring after positioning, for example, the local life information, which is the most extensively used service. Although those position service products bring us great convenience in our daily life, there are no essential distinctions among them. Furthermore, the subsequent service and products are simplification without profound user's attraction.

\section{Some countermeasures and suggestions}

\subsection{Enhanced macro policies supporting}

Policies are the most important safeguard for adjusting and controlling the development of an industry. The relevant departments in Beijing should take the development of LBS industry as chief aim and enhance the study on policies and theories to make relative policies and regulations on LBS market access, industrial pattern, industrial investment, information security, property protection, quality monitoring, technical standardization as early as possible. Making LBS industrial development and revitalizing plan and reinforcing the breakthrough on key technologies will be good to promote the development of LBS industry in Beijing.

\subsection{Accelerating the development and utilization of geographic resources}

Amounts of surveying and mapping results from mapping departments have been under-opening, under-development and inadequate utilization because of involving State secrets or lagging obtainment methods. Maps updating is very slow. The map products are simplification for public to choose. And there is no complete industrial chain system in the market. All in all, to promote and speed up LBS industry development in Beijing, the relevant departments have to deal with the relationship between the development and utilization of surveying and mapping results and the security management as soon as possible. In order to provide a safeguard system on spatial information resources for LBS industry development in Beijing, it is urgent for us to speed up the development and utilization of surveying and mapping results with a precondition of the enriched mapping resources.

\subsection{Enhancing the development of products}

Geographic information responsible departments of government in Beijing should enhance the development of non-confidential products and enlarge the social application of geographic information achievements. Furthermore, the relative supervision departments should also enhance the independent innovation and standardization of LBS business; strengthen the support on research and development work through some demonstrative and boosting projects. Relative supporting policies should been made to promote the exploration of LBS products.

\section{References}

[1] http://news.xinhuanet.com/tech/2011-01/14/c_12982662.htm

[2] http://www.sbsm.gov.cn/article/chyw/201011/20101100075458.shtml

[3] http://www.doc88.com/p-9963638972861.html 
[4] Jia Dan. Considerations and Suggestions of Issues Related to LBS Development in China [C]. World of Geographic Information. 2012:23-24.

[5] Yao Chengkuan. Discuss the Development of the LBS industry in China [C]. Proceedings for the 2009 National Surveying and Mapping Science and Technology Information Sessions and the First Mapping Blog Essay Awards. 2009:142-143 